\title{
SCANNING ELECTRON MICROSCOPE EXAMINATION OF SCALE-LIKE SPINES on the rostellumm of five Davaineinae (Cestoda, Cyclophyllidea)
}

\author{
BÂ C. T.*, SENE TH.* \& MARCHAND B.**
}

\section{Summary :}

The study by scanning electron microscope of the scolex of Cotugnia polyacantha, Raillietina (R.) echinobothrida, R. (R.) tetragona, R. (R.) tunetensis and R. (Skrjabinia) cesticillus allowed us to demonstrate the presence, on the rostellum of each individual, of scale-like spines. We believe that these scale-like spines represent a new character of diagnosis for the whole of the Davaineidae.

KEY WORDS Cotugnia polyacantha. Raillietina (R.) echinobothrida. R. (R.) tetragona. R. (R.) tunetensis. R. (Skriabinia) cesticillus. Davaineidae. Davaineinae. ultrastucture. scanning electron microscopy. scale-like spines.

\section{INTRODUCTION}

T he Davaineidae are parasites, at the adult stage, of the intestine of Birds and Mammals. They have a scolex equipped with four spiny or unarmed suckers and a retractile rostellum bearing one or many rows of hammer-shaped hooks (Yamaguti, 1959; Schmidt, 1986). According to the evolution of the uterus in their gravid segments, they have been subdivided into three sub-families : the Ophryocotylinae with a persistent, sacciform uterus, the Idiogeninae whose uterus is connected with a single paruterine organ and the Davaineinae whose uterus becomes fragmented into egg capsules containing one or several eggs.

Few authors so far have taken an interest in the ultrastructural aspect of these helminths. To our knowledge only few species of Davaineidae have been the subject of transmission electron microscope studies (Blitz \& Schmidt,1973; Polyakova-Krusteva \& Vassilev, 1976a, 1976b; Mackinnon \& Burt, 1983; Swiderski, 1984; Bâ \& Marchand, 1994, 1995). We therefore undertook the study by scanning electron microscope of the scolex of Cotugnia polyacantha (Führmann, 1909), Raillietina (Raillietina) echinobothrida (Megnin, 1880), Raillietina (Raillietina) tetragona

\footnotetext{
* Laboratoire de Parasitologie, Département de Biologie animale, Faculté des Sciences, Université Ch. A. Diop de Dakar, Dakar, Sénégal.

** Laboratoire Arago, Université P. et M. Curie, Paris VI et CNRS, U.R.A. 117, 66650 Banyuls-sur-Mer, France.
}

Résumé : OBSERVATIONS AU MICROSCOPE ÉLECTRONIQUE À BALAYAGE, D'ÉPINES EN FORME D'ÉCAILLES SUR LE ROSTRE DE CINQ DAVAINEINAE (Cestoda, Cyclophyllidea) parasites D'oiseaux.

L'étude au microscope électronique à balayage du scolex de Cotugnia polyacantha, Raillietina (R.) echinobothrida, R. (R.) tetragona, R. (R.) tunetensis et R. (Skriabinia) cesticillus nous a permis de mettre en évidence, sur le rostre de chaque individu, la présence d'épines en forme d'écailles. Nous pensons que ces épines représentent un nouveau critère de diagnose pour l'ensemble des Davaineidae.

MOTS CLES : Cotugnia polyacantha. Raillietina (R.) echinobothrida. R. (R.) tetragona. R. (R.) tunetensis. R. (Skrjabinia) cesticillus. Davaineidae. Davaineinae. ultrastucture. microscopie électronique à balayage. épines en forme d'écailles.

(Molin, 1858), Raillietina (Raillietina) tunetensis (Joyeux \& Houdemer, 1928) and Raillietina (Skrjabinia) cesticillus (Molin, 1858).

\section{MATERIALS AND METHODS}

0 Cotugnia polyacantha and $17 R$. (R.) tunetensis were gathered live from the intestine of Streptopelia senegalensis (Laughing Dove) and $S$. vinacea (Vinaceous Dove). 8 R. (R.) echinobothrida, 16 R. (R.) tetragona and $13 R$. (S.) cesticillus were collected in the same way from the digestive tract of Gallus domesticus. The whole worms were cleaned with a brush in physiological saline (9 \% $\mathrm{NaCl}$ solution) then fixed for 24 hours at $4{ }^{\circ} \mathrm{C}$ in 2.5 $\%$ glutaraldehyde in $0.1 \mathrm{M}$ sodium cacodylate buffer at $\mathrm{pH}$ 7.2. The scolices were removed, dehydrated with ethanol and critical point dried. They were mounted on metal stubs and coated with a gold film by sputtering, before being examined with a Jeol, JSM 35 CF scanning electron microscope.

\section{RESULTS}

COTUGNIA POLYACANTHA (Figs. 1-3)

The scolex, in apical view, is rectangular and measures 350 to $450 \mu \mathrm{m}$ long by 200 to 300 $\mu \mathrm{m}$ wide (Fig. 1). It bears four unarmed circu- 

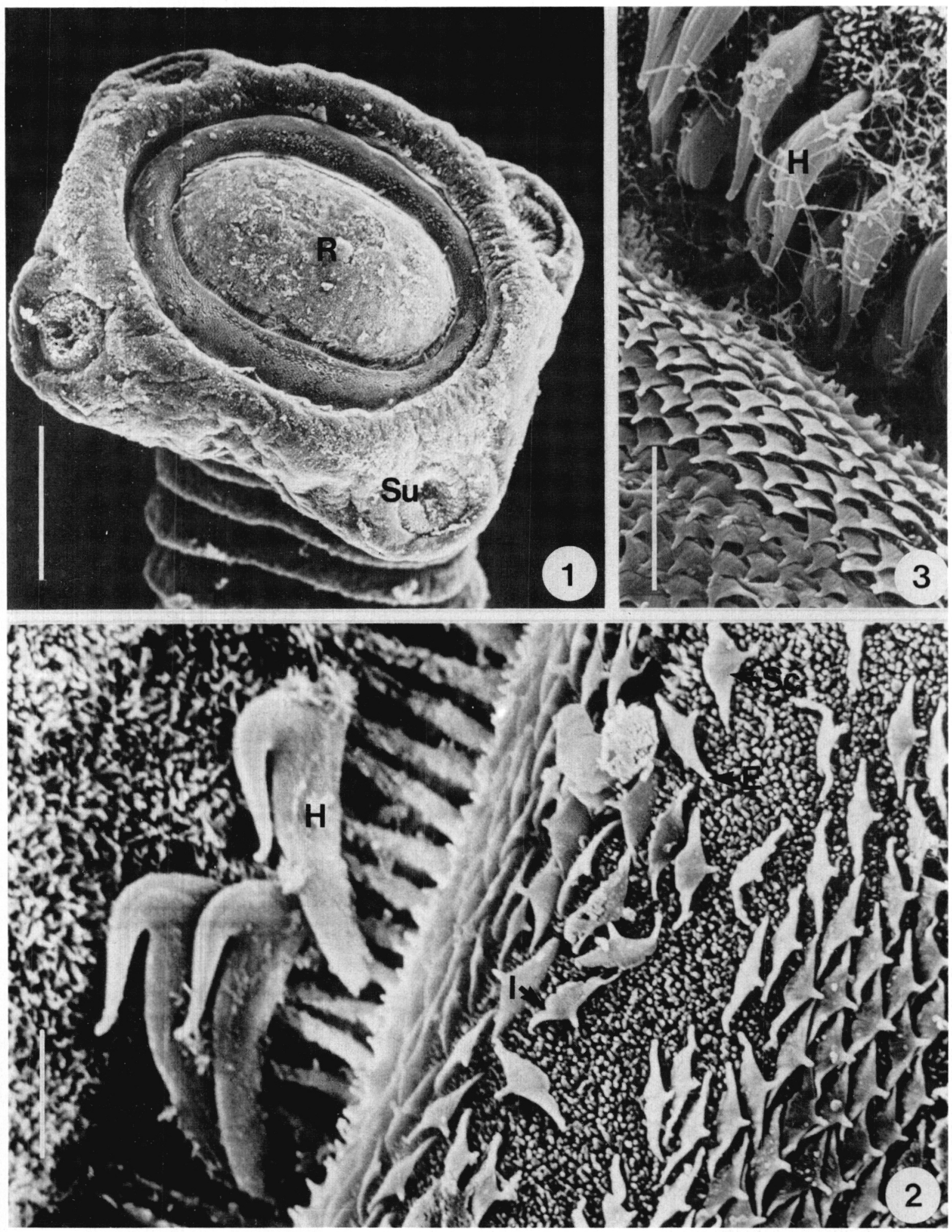

Figs. 1-3. - Cotugnia polyacantha. Fig. 1. - Apical view of the scolex. The rostellum is here invaginated. Bar $=100 \mu \mathrm{m} . \underline{\text { Fig. }} 2$. - Portion of the rostellum. Three hooks and numerous scale-like spines became detached when the worm came away from the mucous membrane of the host's intestine. Bar $=5 \mu \mathrm{m}$. Fig. 3. - Another portion of the rostellum. The hooks form two alternate rows and are orientated, like the scale-like spines, towards the base of the rostellum. Bar $=4 \mu \mathrm{m}$.

E, lateral extension; H, hook; I, indentation; R, rostellum; Sc, scale-like spines; Su, sucker. 

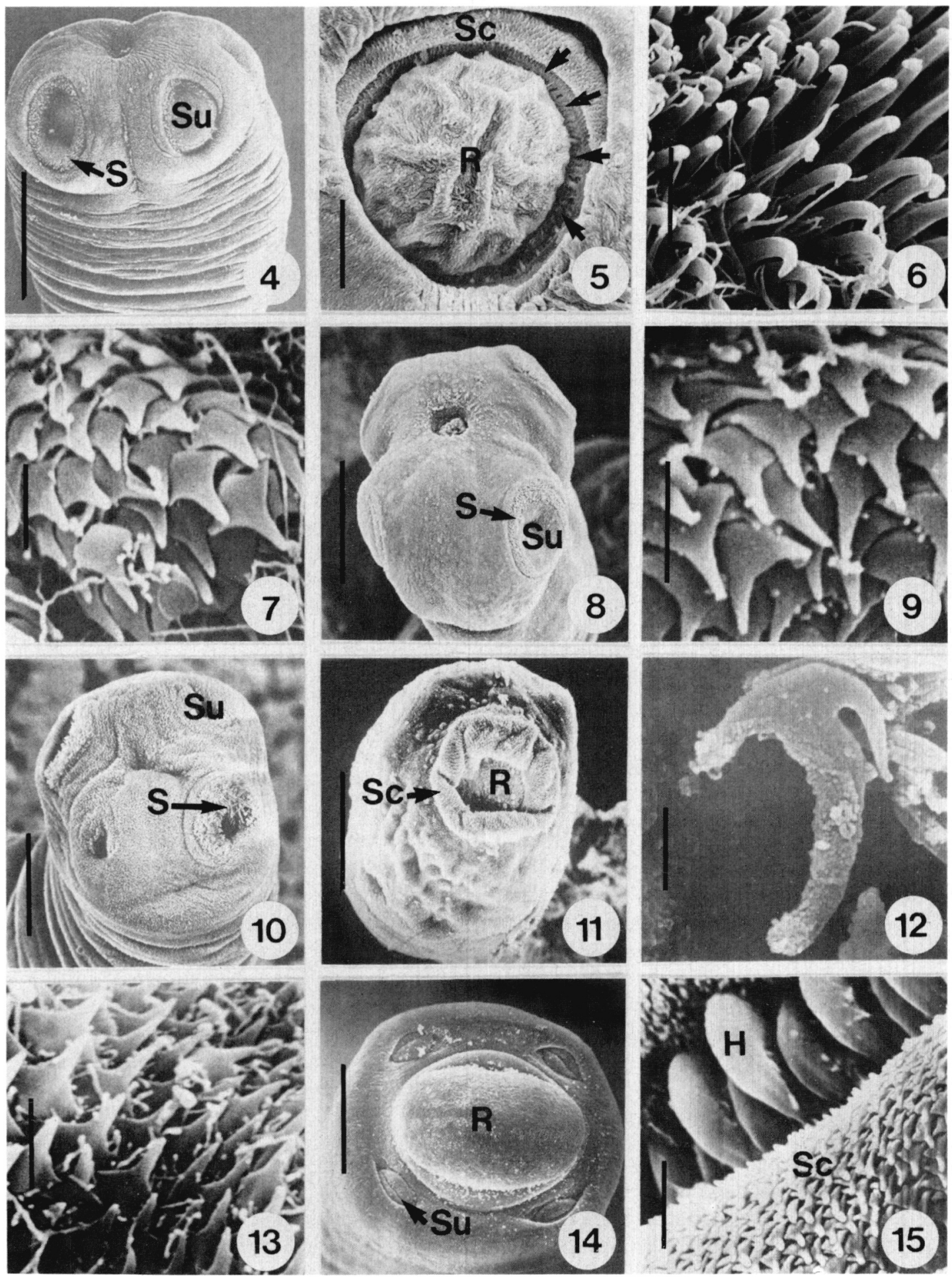

Figs. 4-15. - Scoleces of the four species of the genus Raillietina. Figs. 4-7. - R. (R.) echinobothrida. Fig. 4. - View of the scolex in profile. The rostellum is invaginated. Bar $=50 \mu \mathrm{m}$. Fig. 5. - Apical view of the scolex. The arrows show the position of the hooks which became detached when the worm was removed from the mucous membrane of the host's intestine. Bar $=10 \mu \mathrm{m}$. Fig. $6 .-$ Spines on the suckers of the scolex. Bar $=2 \mu \mathrm{m}$. Fig. 7. - Rostellar scale-like spines. Bar $=1 \mu \mathrm{m}$. Figs. 8, 9. $-R$. (R.) tetragona. Fig. 8. - Scolex. The rostellum is invaginated. Bar $=50$ $\mu \mathrm{m}$. Fig. 9. - Rostellar scale-like spines. Bar $=1 \mu \mathrm{m}$. Figs. 10-13. $-R$. (R.) tunetensis. Fig. 10. - Apical view of the scolex. The rostellum is completely invaginated. Bar $=20 \mu \mathrm{m}$. Fig. 11. - Another apical view of the scolex. The rostellum is partially evaginated. Bar $=20 \mu \mathrm{m}$. Fig. 12. - Hook of the rostellum. Bar $=1 \mu \mathrm{m}$. Fig. 13. - Scale-like spines of the rostellum. Bar $=1 \mu \mathrm{m}$. Figs. 14, 15. $-R$. (Skrjabinia) cesticillus. Fig. 14. - Apical view of the scolex. Bar $=50 \mu \mathrm{m}$. Fig. 15. - Portion of the scolex. Bar $=2 \mu \mathrm{m}$.

$\mathrm{H}$, hook; R, rostellum; S, spines of the suckers; Sc, scale-like spines; Su, sucker. 
lar suckers 90 to $100 \mu \mathrm{m}$ wide and a retractile rostellum. This is 150 to $250 \mu \mathrm{m}$ wide, bears two crowns of about 400 hammer-shaped hooks 9 to $11 \mu \mathrm{m}$ long (Fig. 2) arranged in quincunx (Fig. 3). Behind these hooks, on a 4 to $5 \mu \mathrm{m}$ wide, circular band, numerous very flat spines are found, of an exceptional type that we designate, owing their shape, by the term scalelike spines (Fig. 2). Each scale-like spine is 3.5 to 4 $\mu \mathrm{m}$ wide by 1 to $2 \mu \mathrm{m}$ high. They exhibit bilateral symetry, a slightly convex appearance and comprise : an apical point roughly $0.5 \mu \mathrm{m}$ long, one or two indentations at the base and two lateral extensions (Fig. 2). Moreover, the point is directed towards the base of the rostellum. The scale-like spines are arranged in quincunx and form successive rows which partially cover each other (Fig. 3).

\section{RAILLIETINA (R.) ECHINOBOTHRIDA (Figs. 4-7)}

The scolex is globular and measures 200 to $300 \mu \mathrm{m}$ in diameter. It bears four circular suckers 50 to $100 \mu \mathrm{m}$ in diameter lined with 8 to 12 rows of scale-like spines (Figs. 4, 6). The rostellum is retractile and armed with about 200 to 250 hooks arranged in two crowns measuring 8 to $14 \mu \mathrm{m}$ long. Numerous scalelike spines, arranged as above, form a "collar" under the rostellar hooks (Fis. 5, 7). The apical point of the scale-like spines varies from 0.4 to $0.8 \mu \mathrm{m}$ long.

\section{RAILlietina (R.) TETRAGONA (Figs. 8, 9)}

The scolex is between 150 to $250 \mu \mathrm{m}$ in diameter. It bears four circular suckers roughly $80 \mu \mathrm{m}$ in diameter, each bordered by numerous spines, and a retractile rostellum (Fig. 8). This is armed with hooks 4 to 8 $\mu \mathrm{m}$ long. Scale-like spines, under the rostellar hooks, form several rows which partially cover each other (Fig. 9). The apical point of the scale-like spines is 0.4 to $0.8 \mu \mathrm{m}$ long.

\section{RAILLIETINA (R.) TUNETENSIS (Figs. 10-13)}

The scolex, in apical view, is roughly rounded and measures 80 to $100 \mu \mathrm{m}$ in diameter. It bears four spiny, circular suckers, about $35 \mu \mathrm{m}$ in diameter and a retractile rostellum about $50 \mu \mathrm{m}$ in diameter (Figs. 10, 11). This is equipped with hammer-shaped hooks (Fig. 12) roughly $7 \mu \mathrm{m}$ long and numerous rows of scalelike spines (Figs. 11, 13). The apical point of the scalelike spines varies in length between 0.5 and $0.7 \mu \mathrm{m}$.

\section{RAILLIETINA (SKRJABINIA) CESTICILLUS (Figs. 14, 15)}

The scolex is globular and measures about $250 \mu \mathrm{m}$ in diameter. It bears a rostellum and four small, oval, unarmed suckers with a linear opening. The rostel- lum, roughly 130 to $160 \mu \mathrm{m}$ wide (Fig. 14), is armed with two crowns of hooks 7 to $12 \mu \mathrm{m}$ long and several succesive rows of scale-like spines whose apical point is roughly 0.3 to $0.7 \mu \mathrm{m}$ long (Fig. 15).

\section{DISCUSSION}

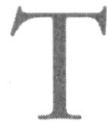

he family Davaineidae "is large and boasts the largest genus of Cestodes : Raillietina, with about 295 species" (Schmidt, 1986). To date, about 54 species of the genus Cotugnia (Diamare, 1893) and 300 species of the genus Raillietina (Fürhmann, 1920) have been described in Birds and Mammals throughout the world (Yamaguti, 1959; Artyukh, 1966; Schmidt, 1986). As far as we know, rostellar spines have only been reported by light microscopy on the rostella of three Ophryocotylinae, five Idiogeninae and nine species of the Davaineinae (Movsesyan, 1977; Beveridge, 1981; Schmidt, 1986; Kornyushin, 1989). By scanning electron microscopy, Gijon-Botella et al., 1989 described for the first time scale-like spines termed "placas puntiagudas cuticulares" on the rostellum of $R$. (R.) micracantha (Fürhman, 1908).

In the present work, we have examined by scanning electron microscopy the scale-like spines covering the base of the rostella of some Davaineinae The specimens we were able to study belong to two genera and five species. By their position and arrangement, we consider them as similar to the rostellar spines for the other species previously described by light microscopy (see above). We also believe that the scale-like spines represent a character which exist in the whole of the Davaineidae. Nevertheless, further scanning electron microscopic studies of a larger number of species and genera belonging to the different subfamilies of Davaineidae are necessary in order to support this statement.

\section{REFERENCES}

ARTYUKH E.S. Essentials of Cestodology. Vol. 6 Davaineidae. Akademia Nauk SSSR, Moscow. 1966, 511 p.

BÂ C.T. \& MARChAND B. : Ultrastructure of spermiogenesis and the spermatozoon of Raillietina (Raillietina) tunetensis (Cyclophyllidea, Davaineidae), intestinal parasite of turtle doves in Senegal. International Journal for Parasitology, 1994, 24, 237-248.

BÂ C.T. \& MarChand B. : Comparative ultrastructure of the spermatozoa of Inermicapsifer guineensis and Inermicapsifer madagascariensis (Cestoda, Anoplacephalidae, Inermicapsiferinae) intestinal parasites of rodents in Senegal. Canadian Journal of Zoology, 1995, in press. 
Beveridge I. Three new species of Calostaurus (Cestoda : Davaineidae) from the New Guinea Wallaby Dorcopsis veterum. Transaction of the Royal Society of South Australia, 1981, 105, 139-147.

Blitz N.M. \& SMYTh J.D. Tegumental ultrastructure of Raillietina cesticillus during larval adult transformation with emphasis on the rostellum. International Journal for Parasitology, 1973, 3, 561-570.

Gijon-Botella H., Del Castillo-Remiro J.A. \& Lopez-Roman R. Estudio al M.E.B. de Raillietina (Raillietina) micracantha Fürhmann, 1908 parasito de Columba livia domestica capturadas en las Islas Canarias. Revista Iberica de Parasitologia, 1989, 49, 37-40.

Kornyushin V.V. Fauna Ukrainy. Vol. 33. Monogenei $i$ Tsestody. Vypusk 3. Davaineoidei. Biuterinoidei. Paruterinoidei. Kiev, Naukova Dumka, 1989, 252 p.

MacKinnon B.M. \& BurT M.D.B. Polymorphism of microtriches in the cysticercoid of Ophryocotyle insignis Lonnberg1 1890 from the limpet Patella vulgata. Canadian Journal of Zoology, 1983, 61,1062-1070.

MOVSESYAN S.O. Tsestody fauny SSSR $i$ sopredel'nykh teritoriy (Davaineaty), Moscow, Izdatel'stvo "Nauka", 1977, 272 p.

Polyakova-Krusteva O. \& Vassilev I. Ultrastructure of the Raillietina caucasia tegument. Khelminthologiya (Helminthology, Publishing House of Bulgarian Academy of Sciences), 1976a, 2, 75-88.

Polyakova-Krusteva O. \& Vassilev I. Ultrastructure of the tegument of Raillietina tetragona. Khelminthologiya (Helminthology, Publishing House of Bulgarian Academy of Sciences), 1976b, 2, 89-102.

Schmidt G.D. Handbook of Tapeworm Identification. Boca Raton, Florida : CRC Press, 1986, 675 p.

SWIDERSKI Z. Ultrastructure of the spermatozoon of the Davaineid cestode, Inermicapsifer madagascariensis. Proceedings of the Electron Microscopy Society of Southern Africa, 1984, 14, 131-132.

YAmaguti S. Systema Helminthum, Vol. 2, The cestodes of Vertebrates. Interscience Publishers, New-York, 1959, $860 \mathrm{p}$.

Accepté le 28 novembre 1994 